\title{
IMAGENS-LEMBRANCCA E IDENTIDADES NO CINEMA INTERCULTURAL DE TILA CHITUNDA
}

Recollection-images and identities in the intercultural cinema of Tila Chitunda Imágenes-recuerdo e identidades en el cine intercultural de Tila Chitunda

> Fernanda Mendes de Mendonça [Universidade Estadual de Campinas, Brasil]

\begin{abstract}
RESUMO Este artigo propõe uma reflexão sobre a presença das imagens de arquivo familiar apresentadas no curta-metragem FotogrÁFRICA, de Tila Chitunda, que nos encaminha a pensar junto ao conceito deleuziano de imagem-lembrança. Fazemos esta análise compreendendo o filme como produto de um cinema intercultural, que se situa na intersecção de dois regimes culturais de conhecimento, neste caso Brasil e Angola, países da rota do Atlântico Negro. Diante dessas imagens, acessamos o que é visível e virtual e exploramos seus aspectos paradoxais. Ao tempo em que se apresentam como registros familiares, as fotografias também expõem a opressão colonial e violência promovida contra identidades e individualidades.

PALAVRAS-CHAVE cinema intercultural; imagem-lembrança; identidade; experiências afro-diaspóricas
\end{abstract}

ABSTRACT This article proposes a reflection about the presence of the family archive images presented in the short film FotogrÁFRICA, by Tila Chitunda, which leads us to think with the Deleuzian concept of recollection-image. We carry out this analysis understanding the film as the product of an intercultural cinema, which is located at the intersection of two cultural knowledge regimes, in this case Brazil and Angola, countries on the Black Atlantic route. In view of these images, we access what is visible and virtual and explore its paradoxical aspects. At the time they are presented as family records, the photographs also expose colonial oppression and violence committed against identities and individualities.

KEYWORDS intercultural cinema; recollection-image; identity; afro-diasporic experiences

* Fernanda Mendes de Mendonça é mestranda do Programa de Pós-Graduação em Multimeios da Unicamp. E-mail: mendesdemendonca@gmail.com. Orcid: https:/ / orcid.org/0000-0001-9327-4083.

Revista Poiésis, Niterói, v. 23, n. 39, p. 278-291, jan./jun. 2022. [DOl: hitps://doi.org/10.22409/poiesis.v23i39.49114] 
MENDONÇA, Fernanda M. Imagens-lembrança e identidades no cinema intercultural de Tila Chitunda.

Revista Poiésis, Niterói, v. 23 , n. 39, p. $278-$ 291 , jan./jun. 2022. [DOI: https://doi. org/10.22409/poiesis.v23i39.49114]

Este documento é distribuído nos termos da licença Creative Commons Atribuição - Não Comercial 4.0 Internacional (CC-BYNC) (C) 2022 Fernanda M. Mendonça. Submetido: 11/3/2021; Aceito: 25/5/2021
RESUMEN Este artículo propone una reflexión acerca de la presencia de imágenes de archivo familiar presentadas en el corto FotogrÁFRICA, de Tila Chitunda, que nos lleva a pensar junto al concepto deleuziano de imagen-memoria. Realizamos este análisis entendiendo la película como producto de un cine intercultural, que se ubica en la intersección de dos regímenes de conocimiento cultural, en este caso Brasil y Angola, países de la ruta del Atlántico Negro. A la vista de estas imágenes, accedemos a lo visible y virtual y exploramos sus aspectos paradójicos. En el momento en que se presentan como registros familiares, las fotografías también exponen la opresión colonial y la violencia promovida contra identidades e individualidades.

PALABRAS CLAVE cine intercultural; imagen-recuerdo; identidad; experiencias afro-diaspóricas 
O que há no espaço entre culturas distintas? $\bigcirc$ que se compreende da amálgama Brasil-Angola, ambos colonizados por Portugal? O que se coloca na bagagem - física, dos bens materiais, e simbólica, dos bens sentimentais, - antes de cruzar o Atlântico? O que fica, o que vai e o que se perde no deslocamento? E como pensar em sobrevivência ou em formas de reexistência mesmo quando tudo ao redor projeta o apagamento? Refletindo sobre memórias, histórias, identidades e imagens do cinema intercultural produzido nas rotas do Atlântico Negro, localizamos o trabalho memorialístico e autobiográfico da diretora, roteirista e produtora Tila Chitunda. Primeira filha brasileira de uma família de angolanos, Tila nasceu e cresceu em Pernambuco, especificamente na cidade de Olinda. Os pais Amélia Sicato e Teodoro Chitunda e seus cinco filhos atravessaram o Atlântico nos anos 1970 como refugiados da guerra civil angolana, declarada logo após o país se tornar independente de Portugal.

Em entrevista transmitida pelo canal do YouTube do grupo Arqueologia do Sensível [2020], a cineasta relata que as fotografias que constituem o arquivo familiar foram recuperadas gradativamente e expostas na parede da sala de estar da casa de sua família em Olinda. Chitunda propõe um olhar para essas fotografias no curta-metragem FotográFRICA [2016]. Esse é o primeiro título da série documental em que investiga memória e identidades através de sua própria trajetória familiar entre Angola e Brasil. Até o momento, a série é constituída por outros dois títulos: Nome de batismo - Alice[2017] e Nome de batismo-Frances [2019]. Nestes curtas, a diretora explora a memória de sua família refugiada e a constituição de uma identidade afro-diaspórica revisitando [e questionando] a história de seu próprio nome: Alice Frances Tilovita Sicato Chitunda.

Propomos concentrar nossa análise no primeiro dos curtas, FotogrÁFRICA, e refletir sobre a presença e afetação das imagens de arquivo familiar atreladas ao conceito de imagem-lembrança [DELEUZE, 2005]. O cinema brasileiro é focalizado em perspectiva transcultural, compreendendo a obra como produto de um cinema realizado no Atlântico Negro. A narrativa do curta compila imagens de arquivo, entrevistas e narrativa em primeira pessoa, articulando o modo poético, que enfatiza a ambiguidade, as fragmentações e derivações no tempo e espaço; e o modo participativo, ao compartilhar o processo de escuta e escavação de memórias familiares em busca de outras perspectivas da história [NICHOLS, 2010].

Cabe observar aqui, considerando nossa recepção fílmica, que a produção evoca uma "leitura documentalizante" na qual a espectadora ou espectador presume como reais as asserções enunciadas 
no filme, como conceitua Odin [2012]. A diretora contribui com o acionamento desse modo de leitura ao apresentar materiais de arquivo, relatos orais e seu próprio testemunho. Esta última característica, inclusive, encaminha para a possibilidade de pensarmos o curta também como uma "EGO produção" [Odin, 1995], filme feito, em geral, para exibição pública, realizado por um membro da família que se expressa individualmente como um eu que não pretende preservar intimidades [confidências e confissões]. O autor distingue três estratégias comunicacionais assumidas nas EGO produções: regimes culturais de conhecimento, no caso Brasil e Angola. Essa característica expressa no cinema intercultural, como explana Laura Marks no livro The skin of the film, produz novas condições para o conhecimento original apagado ou reprimido por regimes dominantes e opressores, re-escrevendo histórias, produzindo arquivos, articulando memória pessoal e coletiva, assumindo outras perspectivas de olhar e construindo fabulações. Com o uso da montagem e através de exercícios imaginativos, torna-se possível a re-existência de imagens até então ausentes. compartilhar uma espécie de processo de "cura psicanalítica", fazer um testemunho e utilizar o espaço público de exibição como meio de comunicação com um ou mais membros da família.

Através de conversas com a mãe, Chitunda expõe conflitos e adaptações vivenciadas por sua família no movimento diaspórico. A narrativa se desenvolve a partir de dois elementos centrais: o jogo de búzios, oráculo comumente utilizado por religiões da diáspora africana e regido pelos Orixás, e o mural fotográfico exposto pela matriarca na parede da sala. FotográFRICA situa-se na intersecção de dois
Uma das características comuns aos filmes e vídeos interculturais é o gesto, ou ação, de revisitar a história oficial, contada sob o ponto de vista dos vencedores, para desconstruí-la, revelar as histórias coloniais e dar a ver outras histórias e formas de conhecimento cultural. Assumimos a compreensão de Marks sobre o cinema intercultural como uma arqueologia de pesquisa através das imagens que revelam vestígios 
e destroços de um passado invisibilizado, ocultado ou incompleto. O cinema intercultural trabalha em paradoxos, sem pretensão de encontrar uma só verdade, e articula um senso de percepção pelo sensível. As produções desse cinema não se propõem a construir uma sólida biografia, com história e causalidade, mas se dispõe a colocar em atrito história e memória, objetivo e subjetivo, real e imaginário, descrição e narração, atual e virtual [MARKS, 2000; DELEUZE, 2005].

\section{IMAGENS E MEMÓRIAS}

Georges Didi-Huberman em Quando as imagens tocam o real questiona que "tipo de conhecimento pode dar lugar à imagem" e "que tipo de contribuição ao conhecimento histórico é capaz de aportar este conhecimento pela imagem". A imagem, nos pensamentos de Didi-Huberman, Gilles Deleuze e Walter Benjamin que aqui iremos imbricar, não é um simples recorte do mundo visível. Há nela sintomas, lembranças, sobrevivências e dialética que articulam outros tempos, fatalmente anacrônicos e heterogêneos.
Gilles Deleuze cria variadas categorizações para a imagem [imagem atual, imagem virtual, imagem óptica, imagem-movimento, imagem-tempo...], mas propomos articular neste artigo principalmente a compreensão de imagem-lembrança - que inevitavelmente se articula a outros conceitos, como de imagem virtual e óptica. Antes de definirmos as imagens-lembrança, precisamos estabelecer as imagens cinematográficas a que nos referimos no cinema intercultural.

A partir das leituras de Bergson, Deleuze estipula o pensamento cinematográfico em: 1] imagem-movimento, que provoca um reconhecimento sensório-motor, orgânico, de causalidade, que aceita a subjetividade implicada na imagem para se sujeitar à forma hegemônica de percepção, ou seja, quando certa percepção predomina sobre outras possíveis; 2] e imagem-tempo, inorgânica, que demanda participação ativa e posicionamento da espectadora ou espectador perante a imagem, decidindo o que é relevante, questionando percepções, objetividades e subjetividades. É nesse último que se situa o cinema intercultural a que nos referimos. Também é através da imagem-

As noções de memória, montagem e dialética estão aí para indicar que as imagens não são nem imediatas, nem fáceis de entender. Por outro lado, nem sequer estão "no presente", como em geral se crê de forma espontânea. E é justamente por que as imagens não estão "no presente" que são capazes de tornar visíveis as relações de tempo mais complexas que incumbem a memória na história [DIDI-HUBERMAN, 2012, p. 213]. -tempo que se dá o acontecimento da imagem-lembrança.

Revista Poiésis, Niterói, v. 23, n. 39, p. 278-291, jan./jun. 2022. [DOl: https://doi.org/10.22409/poiesis.v23i39.49114]

\section{2}


A imagem-lembrança pode ser compreendida como uma memória sobre determinado fato ou momento [pessoal ou coletivo] que não é capturada, portanto não está visivelmente explícita na imagem que se olha. A imagem, cabe enfatizar, é pensada aqui como imaginal, ou seja, que remete propriamente à imagem e se diferencia do imagético que, por sua vez, relaciona-se à imaginação [SANTIAGO JÚNIOR, 2019]. A imagem-lembrança, assim, desafia a história pública e a memória privada, já que remete a um objeto ou acontecimento passado que não se encontra no repertório da imagem atual, que dá a ver o presente que passou. A possibilidade de existência das imagens-lembrança surge no contato com a imagem virtual, uma reação à imagem atual que revela, pelo contato sensível, rastros do passado que persistem e se conservam no presente [DELEUZE, 2005; 1996]. Essa definição se aproxima da imagem dialética pensada por Walter Benjamin, derivada dos destroços da história: ela pressupõe um campo dialético que, ao entrar em contato com o visível, gera um espaçamento entre observador e observado onde se evidencia a historicidade que os envolve. A imagem-lembrança, retomando Marks [2000], confronta o que não pode ser representado e busca colocar o "irrepresentável" em diálogo com a memória.
Relacionamos a concepção de memória aqui expressa com a definição de memória virtual de Didi-Huberman [2013]. Seu acontecimento surge do acesso à imagem por outras vias, que não a do visível, mas do visual. O visual não é visível porque não está no sentido de ser visto, contudo também não é invisível porque é capaz de impressionar o olhar. A concepção de visívele visual está para os conceitos deleuzianos de atuale virtual. Marks [2000] aponta que a imagem, em seu aspecto visívelou atual, é apenas o começo, sendo o movimento de olhar para as imagens o aspecto mais produtivo do cinema intercultural. É no encontro com as imagens de arquivo que se questiona a percepção do olhar e se convoca a espectadora ou espectador à ação de perceber tudo novamente e enxergar lacunas que resultam de "censuras deliberadas ou inconscientes, de destruições, de agressões, de autos de fé" [DIDI-HUBERMAN, 2012].

Partindo desses conceitos, direcionamos agora nosso olhar para algumas fotografias [Fig. 1 e 2] apresentadas em FotogrÁFRICA que remetem à juventude de dona Amélia, nascida em 1939 na região de Catabola, na missão evangélica de Chissamba, colonizada por Portugal. A maioria das fotos, apesar de constituir um arquivo familiar, pouco representa a individualidade da experiência de dona Amélia. O primeiro grupo de imagens 


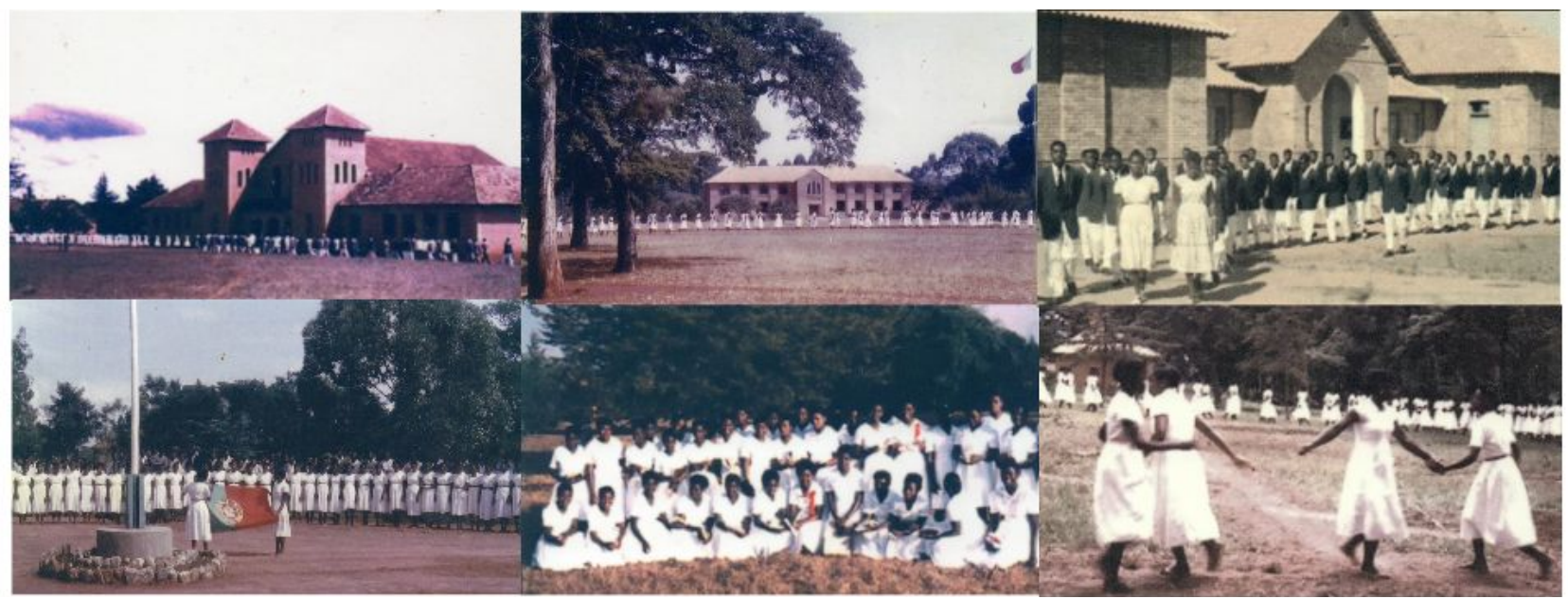

Fig. 1 - Montagem com fotografias apresentadas em FotogrÁFRICA

[Fonte: FOTOGRÁFrICA. Direção e roteiro Tila Chitunda, digital, cor, Pernambuco, Brasil, 25 mim., 2016]

[Fig.1] não aparece em destaque na parede da sala da matriarca por um motivo não dito, mas subentendido. O mural fotográfico montado por dona Amélia reúne fotografias que, como explica a personagem, têm a função de rememorar sua história: "Sempre que eu olho para aquela parede, Alice [Tila Chitunda], eu me lembro exatamente do que aconteceu. Então cada dia eu fico vitalizada com a história da minha família. Não esqueço nada". Esse olhar que rememora e combate o esquecimento - ou o apagamento histórico promovido contra povos colonizados nos relatos de conquista e dominação - nos leva a refletir sobre as imagens-lembrança, que implicam uma outra percepção, que não automática ou habitual, mas de reconhecimento atento [BERGSON apud DELEUZE, 2005]: percebemos de determinada coisa [de uma fotografia, neste caso] uma imagem óptica [e sonora]; uma percepção físico-geométrica e inorgânica, que não ocorre por causalidade.

Ao tempo em que são registros familiares, certas fotografias também são, a nível visível e virtual, registros da opressão colonial e violência cometida contra o povo angolano. Ainda que não haja a provocação para pensar a autoria das fotografias de arquivo apresentadas no curta-metragem ou como se deu o momento anterior ao da captura, em um exercício de imaginação podemos analisar que o autor [homem 
branco europeu, certamente] tinha o objetivo de documentar o sucesso da missão de Chissamba. Distanciado, o fotógrafo enquadra as estruturas arquitetônicas e acompanha cerimônias que mostram uma aglomeração ordeira de corpos negros [em maior parte femininos] reprimidos, dominados, obedientes, que caminham enfileirados e assistem ao hasteamento da bandeira que representa seus opressores.

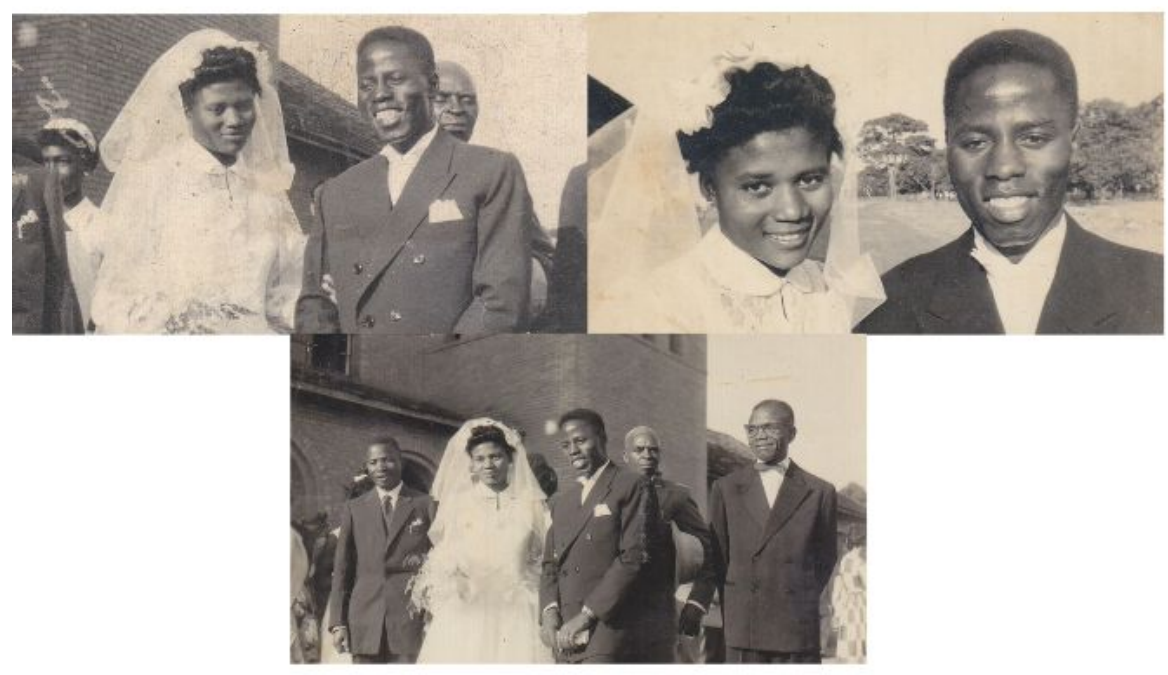

As fotografias não objetivam pluralizar os sujeitos e explorar suas individualidades, pelo contrário: invisibilizam suas diferenças de experiências, subjetividades, relações sociais e essencializam suas identidades [AVTAR BRAH, 2006]. Dezenas de mulheres negras de vestidos brancos e homens negros de ternos escuros participam de um ritual que lhes é estranho e notavelmente incômodo. Seus corpos, quando não aparecem enrijecidos, de cabeças baixas, braços para trás ou colados ao tronco, movimentam-se em uma coreografia que, ainda que remeta a uma identidade cultural própria, é registrada com o distanciamento de quem assiste à manifestação como um voyeur - afinal, para quem aquelas mulheres dançam?

Fig. 2 - Montagem com fotografias apresentadas em FotogrÁFRICA [Fonte: FOTOGRÁFRICA. Direção e roteiro Tila Chitunda, digital, cor, Pernambuco, Brasil, 25 mim., 2016.]

Na narrativa do curta, as três imagens que encerram a sequência de fotografias da missão de Chissamba têm mais proximidade física e afetiva. São registros de um momento da vida particular de dona Amélia: seu casamento [Fig. 2]. O branco do vestido usado na cerimônia de hasteamento da bandeira de Portugal que vemos na sequência anterior [Fig.1] se conecta com o branco do vestido de noiva em frente à igreja cristã. Essas fotografias, diferentemente das anteriores, aparecem expostas no mural da casa e geram um paradoxo entre os elementos simbólicos do processo de colonização e as memórias afetivas da história familiar. 
Outra imagem reveladora das violências simbólicas cometidas contra a existência de dona Amélia enquanto mulher negra nascida em Angola sob regime colonial é descrita oralmente. Seu imaginário guarda a lembrança dos desenhos de crianças "com um rabinho atrás" feitos nos registros de nascimento de sua família. Expondo a perspectiva dos colonizadores sobre os cidadãos de pele preta, ela diz: "O governo que nos colonizava era o gover- no português, ainda tinha a ideia de que o negro veio do macaco. [...] [O desenho era] Uma separação das crianças negras das famílias civilizadas, das crianças negras não civilizadas". A diretora cria uma sobreposição de retratos antigos de seus familiares que atravessam a imagem cinematográfica da entrevista com sua mãe, mostrando que a voz [e a imagem] que fala [e se mostra] no presente reverbera muitas outras antepassadas [Fig. 3].

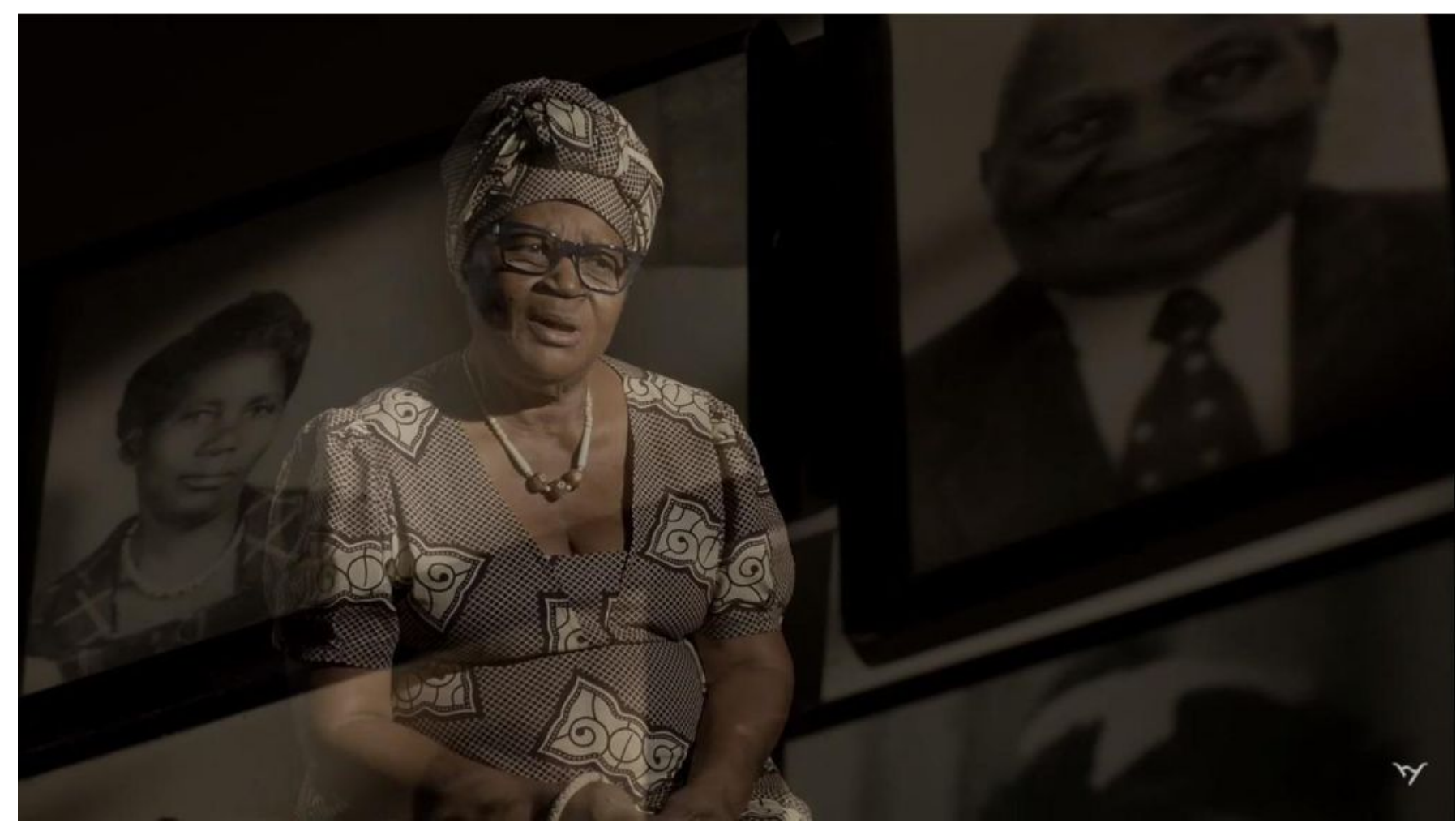

Fig. 3 - Frame com sobreposição de imagens apresentadas em FotogrÁFRICA

[Fonte: FOTOGRÁFRICA. Direção e roteiro Tila Chitunda, digital, cor, Pernambuco, Brasil, 25 mim., 2016.]

Revista Poiésis, Niterói, v. 23, n. 39, p. 278-291, jan./jun. 2022. [DOl: https://doi.org/10.22409/poiesis.v23i39.491 14] 
A narrativa revela imagens-lembrança acessadas por memórias que expõem feridas imaginais e imagéticas causadas por violências sistemáticas do regime colonial, mas que também acessam individualidades e evidenciam afetos possíveis. Chitunda, assim, investiga a rememoração e realiza um trabalho arqueológico, como propõe Marks [2000], nos convidando a olhar e ouvir não o que está visível ou é causal, mas o que está nas lacunas, na ausência, nas imagens-lembrança. Sua pesquisa através das imagens escancara a disjunção entre história oficial e memória privada que revela uma "outra história" em perspectiva, contribuindo com a diversificação do conhecimento histórico aportado pelo conhecimento pela imagem.

\section{TESOUROS VOLÁTEIS}

É necessário mover-se, colocar-se em ação, assumir o reconhecimento atento para possibilitar uma outra forma de acesso às imagens. Esse movimento, contudo, requer uma força, por vezes, dolorosa. As imagens-lembrança, imagens ópticas e virtuais a que nos referimos podem não ser reconciliadoras e, pelo contrário, revelar a incompletude ou "falsidade" da história oficial e das próprias memórias privadas.

\section{Em FotogrÁFRICA, Chitunda faz sua investigação} ciente dos processos implicados, ao narrar em off:

A história a que Chitunda se refere é a da origem de seus pais, crescidos na missão evangélica em Angola, passando pelo fim do regime colonial e enfrentando posteriormente uma guerra civil, condições essas que levaram a família a escapar de seu país de origem e se refugiar no Brasil, especificamente em Olinda, cidade que também se constitui, material e imaterialmente, por processos de colonização e transculturação. Chitunda remexe sua identidade diaspórica na busca por uma origem "pura", mas o que encontra são rastros, sobrevivências e outras formas de existência. 0 contato entre culturas decorrente dos processos coloniais implica disputas de poder, como destaca Stuart Hall em diálogo com Homi Bhabha, que inclui dominador e dominados. O poder não só oprime, invisibiliza, apaga, restringe e inibe: ele também "é produtivo; gera novos discursos, novos tipos de conhecimento [ou seja, o orientalismo], novos objetos de conhecimento [o Oriente] 
e forma novas práticas [colonização] e instituições [governo colonial]" [HALL, 2016, p. 196-197]. Assim, novas identidades e culturas são produzidas por processos de hibridização - na maioria dos casos promovidos forçadamente em situações de colonização, destruição e dominação - a partir das relações conflituosas e assimétricas de poder entre diferentes grupos [nacionais, raciais ou étnicos].

As interrogações feitas por Chitunda sobre seu passado a partir das imagens e do imaginário abre para constelações de sentidos e desconstrói a identidade absoluta e unificada de sujeitos afro-diaspóricos [DIDI HUBERMAN, 2016; HALL, 2016]. O cinema intercultural não apenas explora a intersecção de duas ou mais culturas, como gera novos discursos e conhecimentos culturais produzidos na diáspora. No curta, a imagem-lembrança evocada por uma pintura [não mostrada na imagem, mas apresentada descritivamente] de um Preto Velho da Umbanda exemplifica: enquanto o presbítero da igreja enxerga uma entidade, construída como a representação do pecado e do mal pela matriz cristã eurocêntrica, os pais de Chitunda lembram de um tio que morava com eles na missão em Chissamba. Quando se espera solidez e uma "nova" verdade universal, o cinema intercultural abre a terceira margem para um outro percurso: "eu nunca havia imaginado que o Preto
Velho pudesse ser evangélico", Chitunda fala em sua narrativa em off. As imagens que desestabilizam identidades fixas são os "tesouros voláteis para o cinema intercultural, porque se elas não podem falar por si, podem então ativar o processo de memória" [MARKS, 2000].

Articulando os pensamentos de Homi Bhabha e Kevin Robins, Hall [2006] aponta que os sujeitos das novas diásporas das migrações pós-coloniais habitam, no mínimo, duas identidades, pois já não estão próximos à tradição de uma cultura pura e original. Esses sujeitos gravitam em torno da tradução, quando são obrigados a "renunciar ao sonho ou à ambição de redescobrir um tipo de 'pureza' cultural ou de absolutismo étnico" por estarem submetidos ao plano "da história, da política, da representação e da diferença". Chitunda, ao consultar os búzios na cena de abertura do filme e iniciar sua narrativa almejando encontrar sua origem, tenta recuperar a tradição, mas essa intenção é apenas um ideal intangível. A tradução abre instâncias de complexidade e hibridismo: sua mãe, dona Amélia, praticante do cristianismo evangélico, recusa participar da roda de coco e não frequenta o Candomblé, mas ela também tornou-se referência de uma "mulher africana" na comunidade onde mora por usar torço [turbante] e trajes identificados como "típicos africanos". 
Na percepção de Mãe Beth de Oxum, outra personagem entrevistada por Chitunda em FotogrÁFR/CA que complexifica a definição das identidades, dona Amélia traz na oralidade e em sua imagem a África originária. Entretanto sabemos, a partir do contato com as fotografias do arquivo familiar, que a existência dessa identidade cultural não era possível na Angola colonizada, e só em Olinda, do outro lado do Atlântico, pôde encontrar possibilidades outras de expressão. Paul Gilroy, no livro Atlântico Negro, apresenta como alternativa à leitura romântica e nacionalista de uma "cultura negra pura" um modo transnacional e transhistórico de refletir sobre a experiência negra no mundo, compreendendo que as comunidades dos dois lados do Atlântico estiveram em intercâmbio desde os séculos 18 e 19. Combatendo essencialismos, relativismos e superando binarismos, o sociólogo, em diálogo com Stuart Hall [2006, 2016], defende a dupla consciência e a construção da identidade cultural como um processo de devir, com vontade e poder [GILROY, 2001].

Revelar as imagens-lembrança através de uma arqueologia da imagem praticada no cinema intercultural abre o rizomático arquivo da memória e história afro-diaspórica em FotogrÁFR/CA. Olhar para essas imagens - ainda que difíceis de dominar, organizare entender devido às lacunas e destroços da história - é se arriscar a colocar em interação, a partir de um exercício de imaginação e montagem, os rastros e traços de aspectos que sobreviveram em locais e tempos separados [DIDI-HUBERMAN, 2016]. A ancestralidade de Chitunda não está na Angola de seus pais e irmãos, como também não está no Brasil que a obriga tirar seus "Pretos Velhos da parede". Ela pode ser encontrada no espaço entre-Atlânticos, no Brasil-Angola e nas imagens- lembrança que remexem as cinzas daquilo que queimou, mas sobrevive, apesar de tudo.

NOTAS

[1] No original: "In the face of these erasures, intercultural cinema turns to a variety of sources to come up with new conditions of knowledge: written history, sometimes; the audiovisual archive; collective and personal memory; fiction; and the very lack of images or memories, itself a meaningful record of what can be expressed. Cultural knowledges are lost, found, and created a new in the temporal movement of history and in the spatial movement between places. In this chapter I dwell on archaeological models of cultural memory, while in the next chapter spatial acts of travel and physical contact will predominate. Intercultural cinema moves backward and forward in time, inventing histories and memories in order to posit an alternative to the overwhelming erasures, silences, and lies of official histories". 
BRAH, Avtar. Diferença, diversidade, diferenciação. Cad. Pagu [online]. 2006, n.26, pp.329-376.

CONVERSA aberta com Tila Chitunda. [S. I.: s. n.], 2020. 1 vídeo [128 min]. Publicado pelo canal Arqueologia do Sensivel. Disponivel em: https://www.youtube.com/watch?v=qq9 nyOOECXE. Acesso em: 08 jan. 2021.

DELEUZE, Gilles. A imagem-tempo - [Cinema 2]. São Paulo: Brasiliense, 2005.

DELEUZE, Georges. O atual e o virtual. In: ALLIEZ, E. Deleuze filosofia virtual. São Paulo: Ed.34, pp.47-57, 1996.

DIDI-HUBERMAN, Georges. Diante da imagem. Trad. Paulo Neves. São Paulo: Editora 34, 2013.

DIDI-HUBERMAN, Georges. Quando as imagens tocam o real. PÓS: Revista do Programa de Pós-graduação em Artes da EBA/UFMG, [S. I.], p. 206-219, 2012. Disponível em: https://periodicos.ufmg.br/index.php/revistapos/article/view/15454. Acesso em: 9 jan. 2021.

FOTOGRÁFRICA. Direção e roteiro Tila Chitunda, digital, cor, Pernambuco, Brasil, 25 mim., 2016. Disponível em: https://youtu.be/tsOhCWbgwQg. Acesso em: 08 jan. 2021.

GILROY, Paul. O Atlântico Negro. Modernidade e dupla consciência. São Paulo, Rio de Janeiro: 34/Universidade Cândido Mendes - Centro de Estudos Afro-Asiáticos, 2001.

HALL, Stuart. A identidade cultural na pós-modernidade. Rio de Janeiro: DP\&A, 2006.

HALL, Stuart. Cultura e representação. Rio de Janeiro: Ed. PUC-Rio: Apicuri, 2016. 
MARKS, Laura. U. The skin of the film: Intercultural Cinema, Embodiment, and the Senses. Durham and London: Duke University Press, 2000.

NICHOLS, Bill. Introdução ao documentário. São Paulo: Papirus, 2005.

ODIN, Roger. As produções familiares de cinema e vídeo na era do vídeo e da televisão. Cadernos de Antropologia e Imagem, UERJ, Rio de Janeiro, n. 17, p. 159-172, 2003.

ODIN, Roger. Filme documentário, leitura documentarizante. Significação: Revista de Cultura Audiovisual, [S. I.], v. 39, n. 37, p. 10-30, 2012. DOl: 10.11606/issn.2316-7114.sig.2012.71238. Disponível em: https://www. revistas.usp.br/significacao/article/view/71238. Acesso em: 3 jun. 2021.

SANTIAGO JÚNIOR, Francisco das Chagas Fernandes. A virada e a imagem: história teórica do pictorial/iconic/visual turn e suas implicações para as humanidades. An. mus. paul., São Paulo, v. 27, ed. 08, 2019. 